\title{
Macroeconomic impact of the implementation of energy efficiency houses in Russia
}

\author{
Victor Pchelkin, Galina Kuznetsova, Tamara Zinina, Tatiana Zheltonozhko
}

\begin{abstract}
The purpose of this study is to evaluate the macroeconomic effect of building energy-efficient houses in Russia. One-time investments for energy-efficient house are higher than for standard one due to additional costs of energy saving equipment and technologies, but they lead to specific savings in operating costs per each year of exploitation. As a result, total costs of ownership for a standard and energyefficient house differ in favor of energy-efficient one. We calculate the payback period for additional investments in energy-efficiency for different climatic zones in Russia and accumulated savings for different scenarios of growth of energyefficient house building share in total house building in Russia.
\end{abstract}

Keywords - energy efficiency, methodology, housing, decision maker, state policy

\section{Introduction}

The creation of the country energy-saving and energyefficient housing and communal services is a national target.

The state program of Energy saving and energy efficiency until 2020 [1] establishes a 40\% reduction in energy consumption in the housing and utilities sector. The amount of funding is 70 billion rubles from the federal budget and 625 billion from regional budgets. According to the calculations of Economic Development of the Russian Federation, if the level of energy consumption per unit of GDP reduced to the level of European countries, the annual savings will amount to 180 million rubles.

Solving the problem of energy conservation is complicated by the fact that in Russia there is no experience that forced acquired country in Europe and the US after the energy crises of 1973 and 1978, when price for 1 barrel of oil in 1973 rose from $\$ 2$ to 10 , and in 1978 reached a value of 40 dollars. At the national level governments of developed countries have made unprecedented efforts to gradually mitigate the effects of the 70 s crisis.

Under the influence of the oil shock in the United States and Western European countries related to energy has changed dramatically. Limiting energy consumption standards were introduced and saved billions of dollars. In addition, the state provides their implementation, as even in the United States without the help of the state are not always able to immediately attract business to the energy-saving measures, the effect of the implementation is significantly removed in time from the beginning of investment. Experience has shown that in the energy-saving policy there are certain contradictions that require skillful resolution. Energy supplying organizations disadvantageous to reduce the amount and the number of costs as a result of energy-saving consumer. It seems to be a dead end? But the solution was found.

In the 1980s, special legislation and created economic mechanisms have been developed in the United States and in the developed countries of Europe $[2,3,4,5,6,7,8]$ as a result of the introduction of that energy became unprofitable to sell more resources than was set rules. They have nothing to lose, even if sales fall, as their well-stimulated while reducing power consumption by customers. It made it so that save energy producers become more profitable than selling it anymore. As a result, the power company, first began to actively invest in energy conservation, and, second, revised plans to build new capacity in the direction of reduction. So in 1992, Pacific Gas Company in California made the largest at that time in the world investing in energy-efficient consumer technologies - 170 million dollars. These investments have brought more than $\$ 300$ million net profit. The winner turned out to not only consumers, but also the company's shareholders earned 40 million dollars in profits. In the future, most of the new demand, it was decided to cover the expense of energy saved by the efficient use of its customers.

Studying the positive foreign experience $[9,10,11,12,13]$, it should be noted that our nearest neighbor Republic of Belarus has acquired since 1994 experience in energy conservation and energy efficiency in the residential complex is not inferior to the West. Established the mass production of prefabricated components of energy-efficient buildings and energy-efficient equipment for public utility sector. High level of constructive development of energy-efficient homes and efficient equipment for public utility sector. High theoretical level of energy-saving technology and design quality.

\section{The methodology of forecasting and calculating the economic impact}

In this part of the article presented the methods and techniques to use in the research.

\section{A. Basic technologies of mass energy- efficient housing construction in Russia}

The main purpose of the system as a methodological tool to quantitative assessment of relations between housing costs, incomes and interest rate for a mortgage loan and finding the optimal ratio between these three factors to find the option 
accessibility of housing for families of moderate means by the standards of each region.

The decision maker as a result of the calculations using the list of indicators can see two States of the housing complex of the region: the first condition that must be achieved in order to satisfy all people who need housing and the second actual. The vision of the overall picture will help to find more effective ways of transition from the second state to the first, given its own resources and Federal support.

In a typical Russian apartment building heat losses occur in the following areas (Fig. 1).

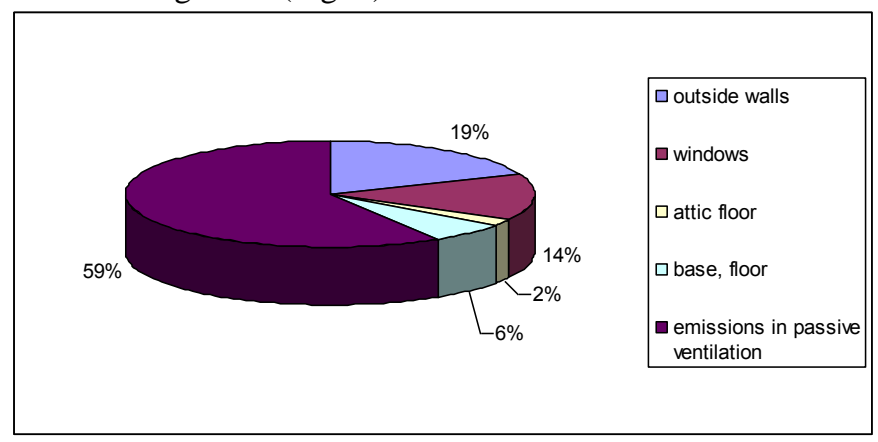

Figure 1. Average specific energy loss for heating in standardized dwellings built on existing standards in Russia

As a well-known technical solutions that reduce the loss of heat energy used for heating of residential buildings, energyefficient construction practices, the following:

- Reduction of heat loss through the building envelope through the use of architectural solutions that minimize the area enclosing structures, while maintaining the volume of building construction;

- Reduction of heat loss through the building envelope opaque by insulation of exterior walls, ceilings attics and basements;

- Reduction of heat loss through the window design by using more energy-efficient windows;

- Reduction of heat loss to the air exchange through the transition to systems controlled ventilation with mechanical drive and recovery (recycling) heat vent emissions;

- Reduction of heat energy consumption for heating by the use of heat pumps;

- Reduction of heat loss during delivery to the consumer by the use of individual heat sources in each apartment or in each building

Total cost of ownership for one house is calculated as follows:

$T C O=K+T \times C$, if constancy of current costs;

$T C O=K+\sum_{j=1}^{T} C_{j}$, if changes in current expenses in time;

$K$ - one-time investment;

$C$ - the fixed operating costs;
$C_{j}$ - the operating costs in j-year;

$T$ - the duration of the period of operation of an apartment house.

In this case, the economic effect of energy saving house operation is calculated as:

$$
\mathrm{E}=T C O_{S}-T C O_{E}=-\Delta K+\sum_{j=\mathbf{1}}^{T} \Delta C_{j}, \text { where }
$$

$\mathrm{TCO}_{S}$ - the total cost of ownership for a standard house;

$T C O_{E}$ - the total cost of ownership energy-efficient home;

$\Delta K$ - the rise in capital investment;

$\Delta C_{j}$ - the savings on operating costs in j-year.

Total cost of ownership for the same house later 1 years of operation $(1<\mathrm{T})$ will be

$$
\operatorname{TCO}_{l}=K+\sum_{j=1}^{l} C_{j}
$$

This indicator allows to track the cost of ownership of the house during building life cycle in dynamics.

Economic effect of energy-efficient houses gained within 1 year from the date of its construction, is defined as

$$
\mathrm{E}_{l}=T C O_{S_{l}}-T C O_{E_{l}}=-\Delta K+\sum_{j=\mathbf{1}}^{l} \Delta C_{j}
$$

The economic effect of the construction of the set $\mathrm{Q}$ sq $\mathrm{m}$ of energy-saving houses, entered into for a certain period and operated during the years 1 can be expressed by going to the specific values of cost, capital costs and savings on current costs per 1 sq. m., as follows:

$$
\mathrm{E}_{l}(Q)=-k_{E} \times Q+\mathrm{c}_{E} \times Q \times l
$$

where

$k_{E}-$ the specific cost of energy saving equipment, RUR per sqm.

$C_{E}$ - the specific savings in operating costs per year, RUR per sqm.

It is assumed that the program input energy saving housing continues for $\mathrm{N}$ years. The input starts in period 1 , and ends in a period, the number $\mathrm{N}$. the Corresponding volume of energysaving housing each year are designated as Q1, Q2,...QN Qi (sq. m).

For each period $\mathrm{t}$ such that $1<\mathrm{t}<$ Tplan, where Tplan is the planning horizon, it is possible to calculate the accumulated economic effect of all energy saving housing built and 
introduced earlier, that is, from housing a total area of $\mathrm{Q} 1+\mathrm{Q} 2+\ldots+\mathrm{Qt}$. It is necessary to consider different periods of housing, depending on the period of its input: for housing the first input queue with a total area of $\mathrm{Q} 1$, the lifetime will be $\mathrm{t}$ years for the housing queue $i$, the period of operation will be $(\mathrm{t}+1-\mathrm{i})$ years.

With this in mind, and formula (3) accumulated economic effect to period $t$ can be defined as follows:

$\mathrm{E}_{t}=-\sum_{i=1}^{t} Q_{i} \times k_{E}+\sum_{i=1}^{t} Q_{i} \times c_{E} \times(t+1-i)$

where $Q_{i}=0$ при $t>N$.

Given that the calculations are projected to be only lifesize - the volume of input and the value and expressed in base year prices, we get the magnitude of costs and savings are given to the base year.

\section{B. The calculation model of the economic effect of the transition to energy-efficient housing construction for different climatic zones in Russia}

Given the differences in the magnitude of annual saving on current costs, you can calculate the payback period of additional investment in energy saving for different climatic zones (table 1).

TABLE I. THE PAYBACK PERIOD OF ADDITIONAL INVESTMENT IN ENERGY SAVING FOR DIFFERENT CLIMATIC ZONES

\begin{tabular}{|c|c|c|c|c|}
\hline Climate zone & $\begin{array}{c}\text { Additional } \\
\text { unit cost of } \\
\text { energy saving } \\
\text { equipment } \\
\text { and } \\
\text { technologies } \\
\text { thousand } \\
\text { rubles for } 1 \\
\text { sq. } \mathrm{m} \text {. } \\
\end{array}$ & $\begin{array}{c}\text { Specific } \\
\text { savings in } \\
\text { operating } \\
\text { costs per } \\
\text { year, } \\
\text { thousand } \\
\text { rubles } \\
\text { per sq. } \\
\text { m. }\end{array}$ & $\begin{array}{c}\text { The } \\
\text { payback } \\
\text { period of } \\
\text { additional } \\
\text { costs, } \\
\text { years }\end{array}$ & $\begin{array}{c}\text { The year in } \\
\text { which pay } \\
\text { back } \\
\text { additional } \\
\text { costs for } \\
\text { houses of the } \\
\text { first stage } \\
\text { (construction } \\
\text { in 2015) } \\
\end{array}$ \\
\hline I & \multirow{5}{*}{1,88} & 0,25 & 7,52 & 2022 \\
\hline II & & 0,38 & 4,95 & 2019 \\
\hline III & & 0,47 & 4,00 & 2019 \\
\hline IV & & 0,53 & 3,55 & 2018 \\
\hline V & & 0,67 & 2,81 & 2017 \\
\hline
\end{tabular}

To select the most optimal scheme of the growth of input energy-efficient housing was formed by several scenarios of this growth and checking the economic effect for each climate zone. For all scenarios the initial proportion of input energyefficient housing in the total housing assumed at $10 \%$ for 2015. The scenarios differ the final target fraction of input energy-efficient housing by 2030, and, correspondingly, the annual growth rate of such share.
The results of applying the scenarios of the calculation of the economic effect of putting energy-efficient housing are shown in table 2. Under positive economic effect for a given year means the excess of accumulated additional investment in energy saving equipment over accumulated savings on current costs from all of the previously introduced energy-efficient housing.

TABLE II. INDICATORS OF THE ECONOMIC EFFECT OF PUTTING ENERGYEFFICIENT HOUSING UNDER DIFFERENT SCENARIOS FOR THE GROWTH OF INPUT (CLIMATE ZONES)

\begin{tabular}{|c|c|c|c|c|}
\hline Climate zone & $\begin{array}{l}\text { The target } \\
\text { share of } \\
\text { energy- } \\
\text { efficient } \\
\text { housing in } \\
\text { the total } \\
\text { input in } \\
2030\end{array}$ & $\begin{array}{l}\text { The total } \\
\text { annual } \\
\text { volume of } \\
\text { housing } \\
\text { construction } \\
\text { in } 2015 \text {, } \\
\text { thousand } \\
\text { square } \\
\text { meters }\end{array}$ & $\begin{array}{c}\text { Year } \\
\text { achieve a } \\
\text { positive } \\
\text { economic } \\
\text { effect }\end{array}$ & $\begin{array}{l}\text { The increase } \\
\text { in economic } \\
\text { benefit in } \\
\text { 2030, million } \\
\text { RUB }\end{array}$ \\
\hline \multirow[b]{3}{*}{ I Climate zone } & $20 \%$ & \multirow{3}{*}{10243} & 2030 & 329 \\
\hline & $40 \%$ & & 2033 & -7190 \\
\hline & $70 \%$ & & 2037 & -18469 \\
\hline \multirow[b]{3}{*}{ II Climate zone } & $20 \%$ & \multirow{3}{*}{31143} & 2024 & 74415 \\
\hline & $40 \%$ & & 2025 & 88259 \\
\hline & $70 \%$ & & 2026 & 109025 \\
\hline \multirow[b]{3}{*}{ III Climate zone } & $20 \%$ & \multirow{3}{*}{15522} & 2022 & 62423 \\
\hline & $40 \%$ & & 2023 & 82989 \\
\hline & $70 \%$ & & 2024 & 111339 \\
\hline \multirow[b]{3}{*}{ IV Climate zone } & $20 \%$ & \multirow{3}{*}{2191} & 2021 & 11194 \\
\hline & $40 \%$ & & 2022 & 15148 \\
\hline & $70 \%$ & & 2022 & 21078 \\
\hline \multirow{3}{*}{ V Climate zone } & $20 \%$ & \multirow{3}{*}{111} & 2019 & 849 \\
\hline & $40 \%$ & & 2021 & 1191 \\
\hline & $70 \%$ & & 2020 & 1703 \\
\hline
\end{tabular}

As can be seen from table 2, the faster the growth of the share of energy-efficient housing in the input the later comes a positive economic effect. This is due to the content and methodology of calculation of this indicator.

The fact that energy-efficient houses of the first stage pay for your own additional investments in energy-efficient equipment in accordance with the payback period for this climate zone (table 3.2). For example, energy-efficient home I climatic zones, built in 2015 , in 2022 , will be worth made the additional investment. After 2022, the savings on operating costs from these houses, from the point of view of calculating the economic impact begins to cover investments in other, newly constructed energy efficient home. The higher the growth rate of input, the less the houses were built first, and the more at the end of the forecast period, the lower the annual saving on current costs from the houses built at first, but the higher the necessary investments in new energy-efficient home at the end of the period. In this context, "coverage" 
investment in new homes due to the economy of the already built takes longer.

The economic effect calculated in this manner is more indicative measure, showing how it is possible at the macro level to ensure that investments in new energy-efficient home due to the financial resources accumulated through savings on current costs from the already commissioned houses.

If we consider the construction of energy efficient homes in General as an investment project, then the decision should focus on the indicator of payback period, which, as noted, is a maximum of 7.52 years for climatic zones I and 2.81 years for the $\mathrm{V}$ climatic zone.

Thus, the construction of each energy-efficient home can be viewed as an investment with a good payback period even for the warmest climatic zone. In this regard, when deciding about the target fraction of the input energy-efficient housing in 2030 will continue to focus on the maximum possible share of $40 \%$ for climate zone and $70 \%$ for II, III, IV and V climatic zones.

This target value is mainly due to the fact that currently about $60 \%$ of housing in Russia as a whole accounts for apartment buildings and about $40 \%$ I / o for individual housing construction (IZHS). Thus in the most southern regions of the Russian Federation in the $\mathrm{I}$ in a climate zone, the share of individual housing construction is more than $60 \%$, while in other subjects an average of about $30-40 \%$.

\section{Problems of realization of the program of mass construction of energy-efficient housing in Russia}

Currently some energy-efficient houses in the Russian Federation are built. We have an experience, capacity, energyefficient appliances and equipment, construction firms with the necessary expertise for the installation and maintenance of energy efficiency equipment, but in general, the construction of energy-efficient homes does not go beyond pilot projects in selected regions of Russia.

The problem of energy-efficient housing construction in Russia is closely connected with the housing problem as a whole due to the standard of living and income of the general population, and adopted public policies aimed at solving housing problems through the mechanism of mortgage lending.

In the context of high interest rates which is a consequence of inflation, mortgage credit is unavailable to the population at large.

Energy efficient homes require more specific investments in the construction of $8-10 \%$. Despite the fact that these costs are repaid no later than 7.5 years in the hottest climate zone of Russia, and after 2.8 years in the most cold, the payback period is generally unacceptable for most investors, which in the end are the people who buy homes.
In this regard at the present time to raise the issue of the mass construction of energy efficient housing in Russia is premature, due to lack of funds from the public, business and government. However, there are two possible directions at the initial stage.

The first is using the experience of construction of individual energy-saving homes, go to the creation of areas of high energy efficiency, and includes the construction of several energy-efficient homes, the rehabilitation of the existing housing stock and the creation of modern public infrastructure, including the construction of cogeneration. In the result, we can obtain the cumulative economic effect, since here the design, construction and operation of tied in a single investment process.

The second resolution on the construction of houses, business class and luxury housing to implement only when projects take into consideration the modern requirements to systems of a heat supply, ventilation, water supply and energy supply.

The implementation of these two approaches allow to work out mechanisms of ensuring energy efficiency in housing and communal complex, which will contribute to further move towards mass construction of energy saving housing.

\section{Conclusions and future developments}

Fuel economy in 2030 in the Russian Federation when entering 412826 square meters efficient housing will be 37,434 tons of conditional fuel or 1139 bln rubles.

At the same return on investment in energy-saving equipment and technology will come in the regions located:

$\square 5$ (extreme) climatic zone - by 2.8 years,

$\square 4$ climatic zone - after 3.5 years

$\square$ in climate zone 3 - 4 years,

$\square$ in the 2 nd climate zone - after 5 years,

$\square 1$ climate zone - by 7.5 years.

This study examines the economic impact of the construction of new energy-efficient homes is the first phase of research.

Equally effective reconstruction of the existing large-panel housing (established in the second half of the last century), given that it will combine energy-saving, major repairs and increase the living space.

These two directions are a real innovation way in construction.

Analysis of new construction and the construction industry showed that currently, energy-efficient homes in the Russian Federation are built: you have the experience, capacity, energy-efficient appliances and equipment, construction firms with the necessary expertise for the installation and maintenance of energy efficient equipment - but in General, 
the construction of energy efficient homes are not beyond the scope of the experiment.

But the most important thing is to link the issue of energy conservation with the main objective of the new housing strategy for creating a multi-sector model that can meet the needs of all segments of the population, on the basis of various forms of housing, with financial support from the state and provided that it policy would be to set the percentage of input energy-saving housing.

Model with various forms of affordable housing should include:

- The commercial sector on a fee basis at market prices, or a private mortgage with the market interest rate;

- The public sector - on a paid basis, with interestfree installments over $8-10$ years at state prices;

- Rental sector private renting at market prices, including hotels, hostels at the established rate;

- The social sector - on the partly paid basis (payment in the form of old apartments) waiting list;

- Sector departmental housing - on a paid basis at market prices, housing for office use only. The customers may be businesses and organizations of all forms of ownership.

The importance of the energy-saving problem is an important part of the adopted policy of modernization of the Russian economy and society. After the last four years have not progressed. As the cause of the failure revealed that the modernisation is not realizable without further democratization and political reform, its fate will ultimately be decided in the field of innovative technologies. The upgrade should be post-industrial and based on priority development of science, education, etc. All this is true, but these General statements do not clarify the specific objectives and necessary actions that can turn the rhetoric (есть такое слово?) of modernization in everyday reality.

The study showed that the achievement of a successful solution to the problem of energy saving in housing and communal complex affects dozens of other socio - economic problems. Confirmed an old truth without solving the General problem of the modernization of the country or at least, choosing the right direction for its solution, it is impossible to positively solve the problem of energy saving in droves.

\section{References}

[1] State program of Energy saving and energy efficiency for the period up to 2020. (in Russian).

[2] Foreign experience of state regulation of the housing sector: economic and legal aspects. / http://metropolys.ru/artic/21/01/c-0024-03254.html (in Russian).

[3] Overview of the foreign property market regulation experience and possibility of its use / http://ros-nedvigimost.ru/publikaciya-polnaya/839 (in Russian).
[4] Pchelkin, V. A., Zheltonozhko T. A. Main directions and perspectives of housing policy in Russia / the Bulletin of the International forum "Housing policy and housing". - Minsk, Belarus, 2013. - p. 23-30 (in Russian).

[5] Maximova D.A., Eremenko M.M., Kostenko E.M., Pchelkin V.A. Comparative analysis of mechanism and social impact of solving the housing problem in Russian Federation and Belarus / Today And Tomorrow of the Russian Economy. - Economic Education, Moscow, №33, 2010. - p. 151-160 (in Russian).

[6] Pchelkin V.A., Polyakova M.B. Managing mortgage mechanism to prevent of the housing crisis in the country. / Real Estate and Investments. Legal regulation. - №3, October 2004. - p. 24-34. (in Russian).

[7] Key Issues and Recommendations for Consumer Protection: Affordability, Social Protection, and Public Participation in Urban Water Sector Reform in Eastern Europe, Caucasus and Central Asia. - OECD, 2003. $-192 \mathrm{p}$.

[8] Lux, M.: State and Local Government: How to Improve the Partnership in: M. Lux (edit- ed): Housing Policy: an End or a New Beginning? LGI Books, Open Society Institute, 2003.

[9] Steffen B. Worst Case Housing Needs 2009: Report to Congress, U.S. Department of Housing and Urban Development, Office of Policy Development and Research, Washington, DC, 2011.

[10] Schwartz, Housing Policy; D. Rice and B. Sar, Decade of Neglect has Weakened Federal Low-Income Programs: New Resources Required to Meet Growing Needs, Center on Budget and Policy Priorities, Washington, DC, 2009.

[11] Desmond M. Unaffordable America: Poverty, housing, and eviction. Fast Focus №22, 2015.

[12] Hegedüs, J. \& Teller, N.: Homeownership and economic transition in Central and East European Countries: Hungary as a case study, in: Horsewood N. and Neuteboom P. (eds) Home Ownership: Limits to Growth, IOS Press: Amsterdam, 2006.

[13] Challenges and Priorities in Housing and Urban Development in the Unece Region. - Short National Reports on Housing and Urban Development. - UNECE, 2015.

About Author (s):

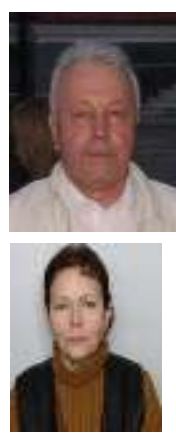

Victor Pchelkin,

Ph.D. in economics, leading researcher of Ministry of economic development of the Russian Federation "Institute of macroeconomic research», Moscow, Russian Federation

\section{Galina Kuznetsova,} Ph.D., Head of the Department of "Institute of Macroeconomic Research", Moscow, Russian Federation

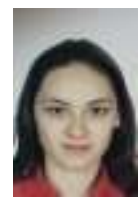

Tatiana Zheltonozhko, leading researcher of Ministry of economic development of the Russian Federation "Institute of macroeconomic research", Moscow, Russian Federation

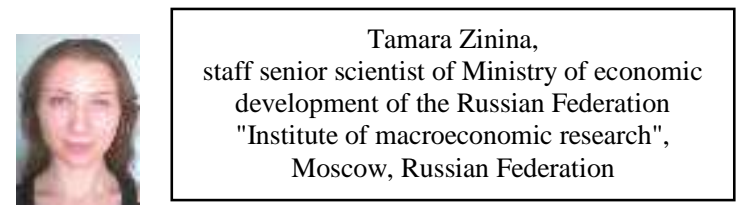

